\title{
Muen Shakai: The Fading of Traditional Values Amidst Modernization of Japanese Society
}

\author{
Yuliani Rahmah* \\ Faculty of Humanities, Diponegoro University
}

\begin{abstract}
Muen shakai is a phenomenon of the people who are separated from their community. Modernization and industrialization have made society more individualistic and less sensitive to the surrounding environment. The traditional values that have been adopted by the community for a long time are slowly disappearing and a new structure is formed in society. With the library research, this article aims to explain the causes of muen shakai and how traditional values are slowly being eroded by the process of modernization. From the results, it is understood that one of the main factors of muen shakai is derived from changes in the family structure that is the main place where traditional values are carried from generation to generation and changes constantly along with the loss of ties in the family and the area of origin.
\end{abstract}

\section{Introduction}

Advances in technology have brought people to modernization without limits. Technology has provided various kinds of changes in human life from time to time. With advances in technology, it is easier for humans to recognize and manage the nature and environment around them. However, in addition to having a positive influence, technological advances can also have negative impacts on human life, one of which is the change of social order.

Japan is one of the countries in the world in which technology has been rapidly progressing and able to create things that were unthinkable in human civilization before. Their sophisticated technology developed into a global commodity that expanded throughout the world, making the country one of the countries whose existence has been known to the wide world. But behind its existence as a developed country, a modernization that developed in that country also had negative impacts on humans' lives. One of them is what is known as muen shakai.

\subsection{Muen Shakai}

The term mиеn shakai was first introduced in 2009 through a report of the Working Poor team at Nippon Housou Kyoku (NHK), a Japanese television center. Since the emergence of this term, communities that discuss the muen shakai phenomenon have begun to emerge. Muen shakai itself has meaning as a part of society that chooses to live individually without

* Corresponding author : yuliani.rahmah@live.undip.ac.id 
the social attachment of its community. The community here can either mean the family or the society around where the individual lives.

Tachibanaki Toshiaki in his book entitled Muen Shakai no Shotai said that initially, Japanese society had the principles of yuen shakai (connected society). In other words, people have a high awareness of the function of the community to help each other and consider it as the core of human life in the family, community, and society. But unfortunately, the characteristics of such a society are now beginning to fade and turn into muen shakai (disconnected society) [1].

The phenomenon of muen shakai itself then gave rise to a new phenomenon that becomes problems for the Japanese government. As a result of the muen shakai, problems that arise are including the cases of kodokushi (died in solitude), high cases of jisatsu (suicide), and even the emergence of hikikomori among young Japanese.

\subsection{Causes of Muen Shakai}

After the destruction of Hiroshima and Nagasaki which were bombarded by allies in World War II, Japan experienced a downturn. Trying to get up and rebuild the country, Japan was finally able to restore the strength of the country which was demonstrated by industrialization and rapid economic growth. The need for human resources to sustain growth and the industry has made Japan experience changes in the field of work. People who initially relied on the agricultural sector switched jobs to the industrial sector in urban areas, and this triggered massive urbanization. Villagers who initially worked as farmers, flocked to the city to become factory workers.

The emergence of factories that require thousands of workers makes people who originally farmed and lived in villages then flocked to the industrial area. The wages that workers get every month also make them bring their families with them to move to industrial areas, causing the emergence of new cities that are located not far from the industrial area [2].

Changes in occupations that require resettlement make workers must be separated from their families. Traditional family arrangements that bind them in a large family, turn into main families or even become individuals who live alone. Relations between families and surrounding communities have become increasingly distant along with the existence of a lifelong work system enacted in the Japanese industrial world. The system causes them to spend more time completing their work. Also, other factors make them no longer able to return to their home regions, such as parents who have died, differences in the principle of life with other family members that cause misunderstanding, and also no more places that can be visited in the area of origin. These factors increasingly distanced the communication between the workers and their communities, so that the sense of brotherhood among them is increasingly disappeared.

This situation later becomes one of the factors that formed the presence of muen shakai. The loss of a sense of brotherhood in blood relations between family members and relationships between friends in the area of origin makes them people who lose their social attachment to their community. The other factor that also has a big role in shaping and forming muen shakai is from the journey of Japan itself.

The phenomenon of muen shakai (無 縁 社会) in Japan was formed from a series of events, namely World War II 'legacy', baby booms, the abolition of shūshinkoyō (終 身 雇用), reduced marriage rates, increased divorce rates, and decreased the number of children born (少子 化) [3, p.121].

Of the various factors that cause the emergence of the muen shakai phenomenon, the family factor is closely related to the traditional values that people hold for a long time. The 
change in the traditional family structure that is transitioning into a modern family has caused a gradual loss of life values in the traditional culture of Japanese society. This is what the writer will explain in this study.

\section{Discussion}

As explained earlier, of the factors that cause the emergence of the muen shakai phenomenon, the writer will explain the family factor as the smallest part of a society and its relation to the traditional values they believe in.

\subsection{Traditional Values in Japanese Society Systems}

Like the people of Indonesia, Japanese society is also a society that lives in an archipelago known as a homogeneous society both racially and culturally. Nakane explained that the homogeneity of Japanese society can be seen from how they group themselves according to certain criteria such as kinship relations, education level, employment, and so on. This is in line with the structure of society which they refer to as Shuudan Shugi. The term refers to a community structure that prefers an individual as one part of a group of people compared to an individual as a person [5].

The system adopted by the society is formed from a concept of Ie (a concept of kinship). According to Tobing, the Ie System takes the form of a large family called daikazoku. Ie members consist of several generations, both living and dead, called sosen or ancestors who became the forerunner to the formation of Ie. The traditional Japanese family adheres to the patrilineal lineage [4,p.74]. The Ie system, the father is the kacho "head of the family" who holds the power and chounan "the first son" is the main heir and successor to Ie. As two people who have a high position in Ie, both kacho who is the head of Ie, and chounan who are candidates for kacho receive special treatment from other Ie members. The system which based on Confucian ethics strictly regulates the hierarchy of superiorsubordinate relations. In a family, a wife must submit to her husband as the kacho (head of the family) and children must submit to their parents [5].

However, this system also brings individual freedom. For example, if the father as the head of the family for some reason is unable to carry out its functions, then the mother will take over the leadership of the family with the assistance of their eldest child [1].

This system then gave birth to the term daikazoku or extended family. Families that adhere to this system, will contain 3-4 generations in a house where all family members have a kinship such as grandparents, father-mother, children, and even grandchildren. The existence of a family like this, too, which in its life preserves traditional values that are reflected through habits and even memorial services and celebrations, will give further strength to the existence of chien (interregional relations) and ketsuen (family or parent relations) and also bring up shaen (social attachment) which is also strong.

\subsection{The Fading of Traditional Values in Modern Japanese Society Systems}

Technological and industrial advancements have had a profound impact on the family structure of Japanese society. Changes in livelihoods lead to massive urbanization of rural communities. The Ie concept which initially became the foundation of the form of the daikazoku family based on chie, ketsuen, and shaen changed to a modern family that only consisted of father and mother and child as the main family. The change in family structure was also strengthened by the abolition of the traditional family system from the constitution 
of the Japanese state. With this, as explained by Rebick \& Takenaka. various family structures are ranging from traditional families that still survive, the main family, families consisting of mothers and children, families that consisting of fathers and children, families consisting of relatives, families consisting of friends, even families whose members are only one person or better known as hitori gurashi in current Japanese society. This also changes the system of social life from a group system to an individualist society [2].

The urban lifestyle that is preferred by the younger generation of Japan causing a rift with the older generation in their daikazoku. This further alienates the generation of workers from their group circles because many of them are reluctant to return to their original places. Their separation from family and group then triggers the existence of tanshinsetai (単 身世 帯), which is a person who lives alone because he/she is not married, divorced or left dead, or because the child has left the house because he/she has lived independently. These tanshinsetai are old and they are called shoggaimikonsha (生涯未婚 者) [3].

It is these community groups that separate themselves from the society so that the phenomenon of muen shakai appears. With muen shakai, some traditional values related to family factors fade and even disappear. The first traditional value that is starting to fade is Ketsuen. Ketsuen is a term that refers to human relations based on blood ties. Lack of communication between family members because of the distance caused a split so that there is no more love between family members. The second value is Chien, a term that refers to a social organization based on a group of families that live in the same area. The attachment of community members because they came from the same area began to fade when some of the members of the community went to urbanize, occupying new places with people from various regions. Because of differences in interests between members of the community in the new area, the sense of attachment between fellow members of the community can no longer be felt. These migrants are more inclined to think about their interests. The absence of ketsuen and chien influences how they adapt to the new environment. The gathering of people from different backgrounds in an organization, work, or community structure is known as shaen. The strength of shaen is generally based on the similarity of ketsuen and chien. However, in urban communities who come from various backgrounds, these two things are not owned. When someone builds a relationship with a colleague, the bond they build is only motivated by a professional relationship at work which then fades when returning to their respective homes. The absence of the three things above (ketsuen, chien, and shaen) causes a higher sense of individualism and a lower level of social concern for others.

The anti-social and apathy attitudes of Japanese society in the modern era has become a phenomenon that is widely discussed in Japan. One of them is the muenshi phenomenon which became a special report of NHK television in January 2010. As explained by Prawiro \& Santoso in an article about muenshi, there are at least 32,000 cases of muenshi that still have a family. It was explained that many people have families, but they do not have a good relationship with other members in the family, causing ties or relationships with their family members to be tenuous or even broken $[6$, p. 7).

Such disharmony makes them have to solve all problems alone. Even when they died, there was no family to take care of or take his body. Some family members who were contacted also submitted the management of the body to the government or approved the handover of the body to be used as material for student practice at the hospital.

Poor relation between family members make the bond of their brotherhood becomes tenuous and even disappear. The absence of relatives who can be relied upon to take care of the death of family members led to the emergence of organizations and businesses engaged in the management of bodies. With more and more Japanese people registering for care 
when they die, it is emphasized that muen shakai is a growing phenomenon in modern Japanese society.

\section{Conclusions}

Muen shakai is one of the unfavorable results of industrialization and modernization. Advances in technology and economics have left a phenomenon of the existence of apathetic and individualistic societies. The values of togetherness of Japanese homogeneous society known as Shudan Shugi because the demands of the modern era are slowly fading replaced by urban communities who choose to become anti-social creatures.

Of the many factors that cause the emergence of muen shakai, the writer argues that the family factor is very influential in changing the structure of society. This is based on the idea that in one's family one can sharpen sensitivity to caring for others. The actions of family members are also based on traditional values taught from generation to generation. When a bond with the family slowly fades, then the value of ketsuen, chien, and shaen which has been the basis of individual awareness of the community will also fade. The need for technology and modern thinking leads to weak individual relations in society. The loss of ties between family members or the home community gave birth to a new perspective on an independent life without the help of others. Unfortunately, the independence that is built by the lack of communication between people makes them isolated until the end of their lives. Also, this situation continues to become a major problem that must be addressed globally by the Japanese government.

\section{References}

[1] Purnomo,Antonius R Pujo., Prosiding of Simposium Nasional Asosiasi Studi Jepang Indonesia (ASJI). (2013)

[2] Devi, Rima., Kajian Jepang Journal. 2.2 (2018)

[3] Prabowo,Roberto Masami \& Tjandra, Sheddy Nagara.Lingua Cultura Journal.8.2 (2014)

[4] Tobing Ekayani ILUNI Kajian Wilayah Jepang Press (2006)

[5] Rahmah, Yuliani.Kiryoku Journal. 1.3 (2017)

[6] Prawiro,Teguh \& Santoso, Budi., Udinus Repository,7 (2015)

[7] Usrina, Linda.Humaniora Journal 6.4(2015) 